\title{
Antecedents and Consequences of Private label brand attitude in the Egyptian Retailers
}

\author{
Reham I. Elseidi, \\ Madiha Metawie,
}

\begin{abstract}
The importance of private label brands has increased; several factors have been affecting the attitude towards private label brands. This research examines the relationship between the antecedents and consequences of private label attitude. A structural model is developed using AMOS version 22, and tested providing indications for the factors affecting the attitude towards private label brands. The results from the structural equation model explained the relationships between store image, familiarity with private label brands, price consciousness, quality consciousness, national brand loyalty and store loyalty on private label attitude. The findings revealed that six hypotheses were accepted and only one had been rejected. The results were discussed in line with the extant literature, showing that familiarity with private label brand is the most important determinant for consumers' attitude toward private label brands. Moreover, as we expected that the attitudes towards PLB products had a positive and significant influenced on private label brand loyalty rather than the store loyalty. Research limitations and Future researches were reported. Implications of

${ }^{1}$ Business Department, Faculty of Commerce, Ain Shams University, Cairo, Egypt Reham.elseidi@commerce.asu.edu.eg

${ }^{2}$ Business Department, Faculty of Commerce, Ain Shams University, Cairo, Egypt madeha74@yhaoo.com
\end{abstract}


these findings on Egyptian hypermarkets and supermarkets are discussed further.

Key words: Private label attitude, Store image, Familiarity with private label brands, Price consciousness, Quality consciousness, National brand loyalty and Store loyalty

\section{Introduction}

Private brands, also labeled as store brands or private labels, are brands developed by retailers. In contrast, national brands are brands developed by manufacturers. The attractiveness of private brands is mainly rooted in their lower prices and less promotional expenses in comparison with national brands (Baltas, 1997; Bao and others, 2011).

The concept of store brands is often used interchangeably with terms such as 'private label brands' or 'own brands' (DelVecchio, 2001; Hoch and Banerji, 1993; Sethuraman and Cole, 1999).

Private labels (PLs) in the consumer packaged goods industry have experienced a worldwide flow in availability and market share in recent years. Accordingly, private label brands (PLBs), consisting of merchandise sold exclusively through a particular retail chain, are growing in importance throughout the world. Retailers are encouraged to sell these brands for different reasons including margin increase, facilitating customer choice and raising customer loyalty (Kumar and Steenkamp, 2007). Other studies by Quelch and Harding, (1996); Richardson et al.,(1996) mentioned that the economic downturn causes a reduction in consumer income; distributors aggressively build a PLB to increase profits and differentiation. Richardson et al., (1996) also added that one of the causes for an expanding PLB is that the manufacturers commit to promoting the brand image and transfer the costs to the customers. This raises prices and 
allows the distributors to participate in the market with lower prices. For retail stores, apart from establishing the differentiation, a PLB can also retain customers and increase profit rate. Therefore, developing a PLB becomes an important strategy for distributors (Wu et al., 2010).

On the other side, Dhar and Hoch (1997), noted that the expansion of private brands has been driven by two key factors: First, by increased consumer recognition of private brands, and, second by retailer motivation for higher profits, partnered with increased retailer capability to manage private brands.

In their study, Beneke and Carter (2015) examined this phenomenon by considering the motivations that attract consumers to purchase private label merchandise and, likewise, those that inhibit such behaviour.

Most previous research on private brands has focused on consumer characteristics that affect private brand purchase intent, such as demographic characteristics (Baltas, 2000; Richardson et al., 1996), value consciousness, (Burton et al., 1998; Richardson et al., 1996). Only a few studies have examined the potential influence of product characteristics on the sales of private brand products (Batra and Sinha, 2000); the effects of perceived product characteristics (i.e. involvement, product type, and switching cost) and consumer value consciousness on private brand purchase intent (Known et al., 2008).

For retailers, SBs become a reliable means to increase sales quickly at a relatively low cost. Consumers are also willing to purchase private brands products (PLMA, 2009) and are happy to have SBs ranges available in grocery stores. Several factors drive consumer willingness to purchase SB products such as economic factors, (Lamer et al., 2007, Jin and Suh, 2005; Kara et al., 2009) and psychographics, (Garretson et al., 2002).

For Jing and Suh (2005), most of the consumer factors associated with SB purchase behaviour can be grouped in three 
categories: personality (e.g., Burton et al., 1998), perceptual (e.g., Garretson et al., 2002), and socioeconomic (e.g., Baltas and Argouslidis, 2007). In previous studies, consumer perceptual characteristics such as price-quality perception, perceived quality, value consciousness, price consciousness, etc. were extensively investigated (Burton et al., 1998; Kara et al., 2009). In addition, Diallo(2012) referred to SB purchase intention to operationalize consumer purchase behaviour toward SBs. In fact, marketing managers to make strategic decisions about both new and existing SB products and the marketing programs that support them commonly use purchase intention data. Purchase intention refers to a consumer tendency to purchase a brand routinely in the future and resist switching to other brands.

Retailers in both Europe and USA launch store brands to increase their profits. Indeed, since the 1990s, store brands have been well known for generating higher margins than national brands (Hoch and Banerji, 1993). They also give the retailer negotiating advantage over the manufacturers of the national brands they compete with (Scott-Morton and Zettelmeyer, 2004) and may improve store loyalty (Corstjens and Lal, 2000). Furthermore, store brands could also play a role in the process of positioning the retailer's shop formula as a brand (Steenkamp et al., 2004). Also known as, "private labels" or "own brands", store brands are exclusive to the retailer chain. Thus, they are associated with the retailer in a unique way, especially when they share the same brand name (Kremer and Viot, 2012).

In addition, the roles and importance of store brands, brands that are exclusive to a particular store chain and compete in several product categories with major manufacturer's brands, have changed dramatically over the past decades. Store brands are developing into developed alternatives, capable of competing 
successfully with these manufacturer's brands on quality as well as on price (Quelch and Harding, 1996) and contributing substantially to profitability, store differentiation and store loyalty (Corstjens and Lal, 2000). Further, store brands can help retailers attract customer traffic and create store loyalty by offering special product lines and premium products (Corstjens and Lal, 2000). Moreover, they present value to consumers by offering a combination of 'good quality' and 'better value' products, and reinforce the retailer's name both on the store shelves and in consumers' homes (Richardson et al., 1996).

It is worthwhile noting that private brands are important to a variety of stakeholders. Manufacturers of national brands view them as potential competitors; stores see them as profit centers and consumer view them as cost-effective alternatives. Marketers seek to win brand loyalty for their brands. Loyalty consists of positive attitudes and preferences for brands leading to their consistent repurchase. Brand loyalty is an opportunity for companies to develop long-term relationships with customers. (Goldsmith et al., 2010)

\section{Conceptual Framework and Hypotheses :}

\subsection{Store Image}

AilAwadi and Keller (2004) define store image as a retailer's impression in the mind of the consumer. In addition, the concept of store image, considered as the way consumers see the store in their minds, based on tangible and intangible attributes, deserved a great deal of academic and empirical attention, during the last four decades. The importance of studying the image is based on the notion that the store possessing the most compatible attributes with the image desired by consumer will have a better chance of being selected and visited (Amirani and Gates, 1993). Therefore, the store image can be used as a 
marketing tool (Engel et al., 1995), or as a competition tool (Reardon et al., 1995), providing valuable indications to managers about the most and the least attributes appealing to consumers, and therefore, the insights for the marketing mix conception (Farhangmehret al., 2001).

On the other hand, Martineau (1958) presented the concept of store image and defined it as the way in which the shopper's mind pictures the store, partly by its functional qualities and partially by its atmosphere of psychological characteristics. James et al.,(1976) defined store image as "a set of attitudes based upon evaluation of those store attributes considered important by consumers.' Grewal et al.,(1998) mentioned that a store's consuming environment, service level, and product quality are so-called store image. In summary, store image could be defined as the perception of consumers based on the multiattributes of a store; intrinsic and extrinsic (Wu et al., 2010).

Most definitions confirm that store image is a holistic measurement in which the shopper evaluates components forming essential parts of their store evaluations (Angell et al., 2014).

Continuous conceptions of store image have taken into account the interactions among attribute perceptions (Hartman and Spiro, 2005). Lindquist (1974) studied store image structure across nine dimensions: merchandise, service, clientele, physical facilities, convenience, promotion, store ambience, institutional factors and post transaction satisfaction. These dimensions have been widely studied and discussed in previous research and most of them are merged into store image scales (e.g., Grewal et al., 1998; Smeijn et al., 2004). Most of the time, store image is considered as a multi-dimensional concept including various aspects of the retail store. 
The impression of the store image is determined by a complex combination of both functional and psychological characteristics associated with the retailer (Chang and Tu, 2005; Ailawadi and Keller, 2004; de Giraldi et al., 2003). Diallo, 2012; Bao et al., 2011; Jin and Suh, 2005; Ailawadi and Keller, 2004; Semeijn et al., 2004; Vahie and Paswan, 2006, agreed that a number of retailer attributes influence overall store image, the most common including merchandise quality, store quality, store atmosphere, layout, service, convenience, price level, and assortment.

Store image is revealed in the store's physical environment (Richardson et al., 1996), perceptions related to its merchandise, and perceived service quality (Baker et al., 1994). Consumers use these cues to form a complete evaluation that will affect their attitude toward the store as a whole, and potentially towards its store brands (Semeijn et al., 2004). The previous study stated that there is a direct positive relationship between perceived store image and consumer attitudes towards store branded products. The more highly a consumer thinks of a store the more positively he/she will evaluate store-branded products. Three store image factors were considered in this study: layout, merchandise and service. Kremer and Viot, (2012) also demonstrated that the retailer image or the store image helps fuel attitudes towards store brands.

Numbers of studies, (Vahie and Paswan, 2006; Semeijn et al., 2004; 2003; Richardson et al., 1996) agreed that the presence of store image as a factor in the conceptual model stemmed from evidence that store image has a positive, direct effect on consumer evaluation of PLBs. In specific, these studies have found that store image has a remarkable effect on the perceived product quality of a PLB. 
On the other hand, Beneke and Carter, (2015) indicated that store image influences the perceived product quality of private label branded products. Further to this, Richardson et al., (1996) suggested that if consumers find a store to be unattractive, they assign these traits to the store's private label branded merchandise, thus diminishing the perceived product quality.

In addition, Kremer and Viot (2012) concluded that store brands have a positive impact on the retailer image indicated that store brand image includes three dimensions: price, supply and values. The price dimension refers to low prices, good deals and value for money. The supply dimension relates to the perceived quality of store brands, packaging, and innovation and to the possibility of customers deciding between national brands and store brands. The third and final dimension connects values such as closeness, affordability, convenience and sustainability. The study suggested that a range of store brands that is attractive in both quality and variety, with appealing packaging and innovative products, reinforces the perception that the retailer is providing its customers with a wide collection of good products in a pleasant shopping environment.

$\mathrm{Wu}$ et al.,(2010) in their study stated, that store image has a direct and positive effect on the purchase intention of the PLB. In addition, they indicated that Cosmed, a popular chain of drugstores in Taiwan, ensures good quality service by providing consumers with a pleasant physical service environment and a nice shopping experience, successfully enhancing its PLB image.

While there is a mutual influence between store image and individual store brand image, the influence is stronger from the store to the brand than in the opposite direction. In other words, when consumers have tried the store brand, their view about it will have a potential influence on the store image, but it is more 
likely that the image of the store already influenced consumers' willingness to try the brand (Martenson, 2007).

In their studies, Ailawadi and Keller(2004); and Dhar and Hock (1997), showed that consumers would use the store image as one of the extrinsic cues to judge the private label brands. When consumers have a high perception of a store image, it creates a positive effect on the brands carried by the store (Dhar and Hock, 1997). In addition, Vahie and Paswan(2006) stated that when a certain private label brand is not popular, consumers guess the PLB image from the image of the retail store. Therefore, store image has a direct and positive relationship with consumers' purchase intention for PLB. The research results confirm that the quality dimension of the store image affects the quality and affection dimensions of the PLB image.

It is worth noting that studies done in the environment of grocery store have shown that consumers have a more positive attitude towards grocery PLBs if they have a high image of that particular store (Collins-Dodd and Lindley, 2003). Vahie and Paswan(2006) also suggested that when consumers find shopping at a store very convenient and get good value for money, the good feeling is likely to enhance their liking towards the private label brands as well.

Zielke and Dobbelstein (2007) concluded that the attitude towards store brands in general is a predictor of the attitude towards a specific store brand.

Based on the previous discussion, the following hypothesis is suggested:

H1: There is a significant positive association between store image and the attitude towards private label brand.

\subsection{Familiarity with private label brand}

Brand familiarity with products or services arises from a number of interactions that a consumer has with the brand. The 
brand becomes familiar because of multiple reasons such as brand associations, prior exposure, brand usage, word of mouth and advertisement (Bapat, 2017).

Alba and Hutchinson (1987) defined brand familiarity as the number of brand-related direct or indirect involvements that have been accumulated by the consumer. Brand experiences such as exposure to numerous media advertisements for the brand, purchase or usage of the brand and exposure to the brand in a store, increase brand familiarity, and are a significant internal source of information. Brand familiarity can be higher by frequent exposure to the brand (Park and Stoel, 2005). Familiar brands may achieve better recall and are better able to be protected from competitive advertising interference than less familiar brands (Kent and Allen, 1994).

Aaker and Joachimsthaler (2009) indicated that consumers shape a conceptual image of brands in their minds over time. The conceptual image is derived from a number of sources, including traditional advertising (Arens et al., 2012; Agrawal, 1996), actual experience of using the brand (Erdem and Swait,1998) as well as word of mouth with friends, family and colleagues (Allsop et al.,2007; Brown et al., 2007). This means that the external influences, if positive in nature, can lead to favorable quality perceptions of the brand and hence influence the consumer's view of the private label (Beneke and Carter, 2015).

Ballester et al.,(2012) indicated that as far as familiar brands are both more perceptual and conceptual fluent than unfamiliar brands, because they can be recognized and identified more easily and come to mind more readily, they enjoy more cognitive and affective advantages. Dursun et al., (2011) also recognized that familiarity significantly influences a consumer's brand choice through a number of channels, including generating positive affect towards the brand as well as encouraging purchasing behavior. 
Zajonc and Markus (1982) found that continuous exposure to objects lead to positive attitude towards these objects and that the exposure effect is a basic process in preference and attitude formation and change. Besides, Laroche et al.,(1996) also concluded that a consumer's attitude toward a specific brand would be positively affected by his/her familiarity with the brand. Consistent with this study, Sen and Johnson (1997) found that familiarity resulting from the mere possession of a brand could lead to positive evaluation of the brand.

Hence, from the previous studies, the following hypothesis could be proposed:

H2: There is a significant positive association between familiarity with private label brands and consumers attitude toward the private label brand.

\subsection{Price consciousness}

Price consciousness has been defined as a buyer's "unwillingness" to pay a higher price and as the "degree to which the consumer focuses exclusively on paying low prices" (Lichtenstein, 1993; Sinha and Batra, 1999). Wu et al., (2010) define price consciousness as the level consumers value for price when choosing a certain product, in which consumers tend to use price as the judgment standard for purchasing and adopt low cost strategies.

Fan and Xiao, (1998) studied price consciousness on scale in which consumers who score high on this factor arc very price conscious. They cautiously watch how much money they spend, compare prices of different brands at different stores before making a purchase, and tend to purchase products with low prices.

Store brands have been identified as price-sensitive products (Baltas, 1997; Sethuraman and Cole, 1999), and numerous studies confirm the significant effect of price consciousness on 
attitude towards store brands, including Baltas (1997), Burton et al., (1998), Batra and Sinha (2000), and Jin and Suh (2005). In addition, Rubio et al., (2015) indicated that due to the characteristics of store brands, their target market has traditionally been price-conscious consumers who seek utilitarian/economic benefits in their purchases. As consumers are attracted to PLB for their low prices. This leads to an increase in the probability of consumers to purchase PLB products (Batra and Sinha, 2000; Burton et al., 1998). Consistent with the previous, Glynn and Chen(2009) indicated that since PLBs are typically lower in price relative to national brand products, studies have often used price consciousness as one of the elements determining the characteristics of PLB buyers. They added that price consciousness strongly affects PLB buying in most types such as canned fruit and milk, but not in others like potato chips, biscuits and toilet tissue.

It is worth to note that buyers' opinions of price, affect their evaluations and attitudes towards product. Obviously, consumers' perceptions of price vary because of their different backgrounds, situations, and competitive choices (Dodds, 1995)

Based on this discussion, the following hypothesis is advanced:

H3: There is a significant positive association between price consciousness and attitude toward the private label brand.

\subsection{Quality consciousness}

In comparison to price-conscious consumers, quality-conscious consumers are primarily concerned with product quality (Sproles and Kendall, 1986). Quality-conscious consumers have a negative attitude toward store brands (Ailawadi et al., 2001; Veloutsou et al., 2004) as brands with lower perceived quality than manufacturer brands (Del Vecchio, 2001; Richardson et al., 1996). Consumers feel confidence in purchasing the products that are perceived to be of a higher quality (Jaafar et al., 2012). 
It is worth to note that consumers assume private label brands, product quality mainly with extrinsic cues such as brand name, packaging and price (Vahie and Paswan, 2006). Brands are those sold under retailers, Richardsonet al., (1996) noted that quality perception is vital that it mainly determines not only the purchase of a private brand, but also the market share, thus, to increase sales of private brands, retailers should put more weight on quality as opposed to positioning on low price.

In the same vein, Veloutsouet al.,(2004); Zielke and Dobbelstein(2007) indicated that perceived quality and the importance of different characteristics have an influence on the willingness to buy store brands.

Hence, we propose that

H4: There is a significant negative association between quality consciousness and attitude towards private label brand.

\subsection{National brand loyalty}

Brand loyal consumers show a stronger tendency to buy the same brands they have always bought and, compared to those who are more likely to seek variety, are less likely to switch to new and unfamiliar brands. Past researchers have suggested that consumers concerned with paying lower prices are less loyal toward specific brands (Blattberg and Neslin, 1990).

Ailawadi (2001) recognized that consumer preferences for national brands are strong and that a competitive national brand assortment is important for retail profitability although store brands do provide advantage to retailers and allow retailers to increase profits. In other words, national brands enjoy a level of equity and image, over and above quality, that is not offset by the lower price of store brands.

While existing research proves that brand loyal consumers are not likely to be involved in searching for other brands, it is 
possible to anticipate that loyal consumers will hold more negative attitudes toward private label brands than toward national brands. Unlike national brands, store brands are likely to be less familiar to consumers because few store brands are promoted with professionally developed national campaigns (Krishnamurthi and Raj, 1991).

Consistent with the previous studies, Vahie and Paswan (2006) indicated that the presence of national brand would affect the private label image particularly when considered in combination with the store image. However, this image transfer may not carry over to the private label brand, and consumers who are national brand conscious may point negative quality to the private label brand. This means that even if consumers perceive the presence of national brand to be in harmony with the store image, it is not likely to help the private label brand. Probably, this harmony is likely to harm the consumer's perception of PLB.

Based on this discussion, the following hypothesis is advanced:

H5: There is a significant negative association between loyalty to national brands and attitude toward the private label brand.

\subsection{Private label brand Loyalty}

It is apparent that a consumer, who is loyal to a particular store brand, establishes a high level of brand recall. In addition, it is likely that this particular store brand enjoys a favorable brand image (De Wulf et al., 2005).

Store brands might improve customer loyalty toward retailers because they offer a means of differentiation (Collins-Dodd and Lindley 2003; Richardson et al., 1996). Empirical studies support a positive correlation between store loyalty and store 
brand purchase (Ailawadi et al., 2001; Kumar and Steenkamp 2007).

SBs achieve loyalty among heavy SB buyers, who are primarily conscious of price and perceive high value for money in SBs due to their competitive prices. Although heavy buyers are loyal to SBs for their prices, they might stop acquiring them if they find other, cheaper options (Rubioet al., 2015). It is important to note that there is a positive relationship between retail brand attitude and retail brand loyalty (Cho et al., 2015).

Based on this discussion, the following hypothesis is advanced:

H6: There is a significant positive association between private label brand loyalty and attitude toward the private label brand.

\subsection{Store Loyalty}

Store loyalty refers to the consumer's inclination to buy from a given store or chain of stores over time. While expressions of store loyalty and customer retention are often used as a replacement for buying behavior patterns, they are seldom measured. Many analysts choose to use the measure of repeat store visits as a convenient expression for store loyalty, despite the obvious shortcoming of the disregard for the actual amount being spent in the store (Knox, and Denison, 2000). On the other side, Pepe(2001) commonly used measures of store loyalty in prior research studies which have incorporated variables such as percentage of purchases at a particular store, dollars spent, frequency of patronage, and degree of store switching.

The ultimate goal of most retailers is to have loyal customers. Loyalty can be an outcome of customer satisfaction (Oliver, 1997). Ailawadi et al., (2001) and Kumar and Steenkamp, (2007) found a positive correlation between PL use and store loyalty. In addition, consumers who consistently shop at the chain are more likely to attribute this shopping behavior to the chain's quality 
and may be more positively willing to buy PL (Ailawadi et al.,2008). On the other hand, the ability of PLs to increase store loyalty in Corstjens and Lai's (2000) model is also based on a "balance" between consumers who prefer PLs and those who prefer NBs. It is worthy to note that Cho et al., (2015) concluded that retail brand attitudes positively affect store loyalty.

Based on this discussion, the following hypothesis is advanced:

H7: There is a significant positive association between store loyalty and attitude toward the private label brand.

Consequently, figure (1) depicts the conceptual framework which was developed to assess the five antecedents on the consumers' attitude towards the PLBs products and their consequences in the Egyptian retailers' context.

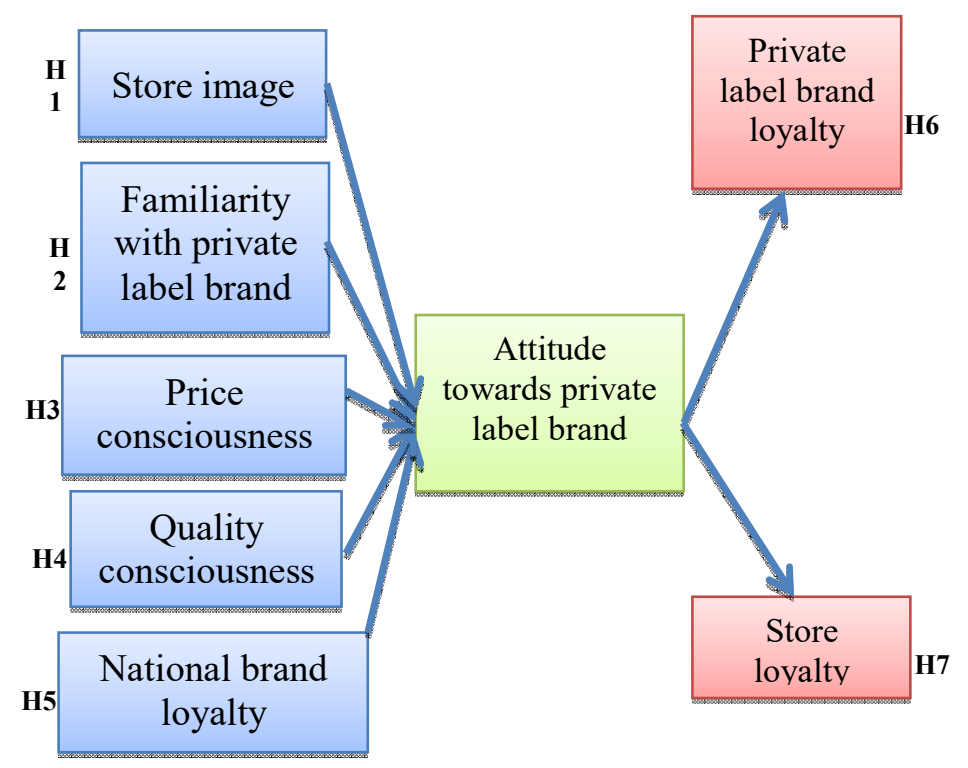

Figure 1. Hypothesized Research Model 


\section{Research Methodology}

\section{3-1 Sample and Data collection}

The research population consists of consumers who have been shopping for private label brand products at hypermarkets/supermarkets such as Carrefour, Hyper one, Spinneys, and khair Zaman in the greatest Cairo in Egypt. Data was collected via a mall-intercept method using selfadministered questionnaires during summer and autumn 2017 in the weekdays and weekends to obtain more information for different shopping patterns and crowds. Three teaching and research assistants helped the researchers to collect the questionnaires from the respondents at different branches of hypermarket and supermarkets in the greatest Cairo in Egypt. Additionally, the questionnaires were given to those respondents who agreed to participate in this research and they regularly purchase private label brand products. A total amount of 540 questionnaires were delivered, while 418 effective questionnaires were returned, yielding a reasonably high response rate of about 77.4 percent. The sample was skewed in favor of female respondents (66 percent versus 34 percent male respondents), younger consumers (constituting 63.4 percent of the sample, particularly consumers aged $20-40$ years) and half of them (50 percent) their monthly income from L.E. 1200 - less than L.E. 3200. A large percentage of consumers who married and have kids was included in the sample (47.8 percent versus 23 percent and 25 percent for consumers who got married but they do not have kids and single consumers respectively). In addition, more than half of the sample (55 percent) was working on a full-time basis versus 25 percent on a part-time basis, and the rest of the sample were housewives and unemployed. The descriptive analysis also shows that the majority of the sample (31.3 percent) was purchasing toilets papers and tissues from the 
retailer brand versus 28.2 percent and 25.8 percent were purchasing detergents and dry food respectively.

\subsection{Measurement}

The researchers examined scales used previously in the previous academic literature, to measure the proposed concepts. Specifically, store image was measured by seven items, adapted from previous studies (Mazursky and Jacoby, 1986; Hopkins and Alford, 2001). To measure familiarity with private label brand, five items have been adopted from the scale by Mieres et al., (2006) and Porral et al., (2016). For quality consciousness, we used three statements from the scale of Sproles and Kendall (1986) which was used subsequently by other authors (Yang and Wang 2010; Rubio et al., 2015). Price consciousness was measured with four items developed by Sinha and Batra (1999) that have been used often in the context of private brand by Yang and Wang (2010), Rubio et al., (2015) and Wu et al., (2011). The scale on National brand loyalty is constructed by adapting the scales proposed by Cho et al., (2015) which they had been developed based on prior researches and Ailawadi et al., (2001) using six items. Private label brand loyalty was examined following Yoo, Donthu and Lee, (2000); Oliver, (1980); Rondan Cataluna, (2006) through five items. Store loyalty was measured with six items combined and adapted from previous studies either in the field of the private label brand or outside this context (Yoo and Donthu, 2001, Zeithaml et al., 1996; Soyoung and Byoungho, 2001). Finally, consumers' attitudes toward private label brand were measured with six statements from the scale of Burton et al., (1998). Moreover, each item in the questionnaire was measured on a scale of 1 to 5 with anchors "strongly disagree" to "strongly agree" for the constructs measures. Due to the consistency reasons and to validate the interpretation of the scales used, the questionnaire 
was translated into Arabic and then back into English by the researchers and a bilingual translator. The questionnaire consists of three sections, the first one included a filter question whether the consumers have purchased before private label brand or not. Additionally, some questions related to their shopping patterns, the private label brand products that they have been purchasing and their preferred store. Second section, has some questions related to the proposed model and the measurement for the constructs. Finally, the third section included questions for personal information and the participants' demographics characteristic. Further, a pre-test of the questionnaire was conducted before the final one, with 24 interviewers to enable the amelioration of the measurement scales and the checking for any ambiguous questions. As a result, few statements were worded to clarify the meaning and some elements of terminology.

\subsection{Data analysis}

The researchers carried out the data analysis of this study in two steps as suggested by Anderson and Gerbing (1988) for assessing the measurement and structural model by covariance based SEM using AMOS 22.

\section{Results}

\subsection{Analysis of the measurement model}

The measurement model comprising store image, familiarity, price consciousness, quality consciousness, national brand loyalty, attitudes toward private label brands, store loyalty and loyalty toward private label brand was analyzed using confirmatory factor analysis (CFA) by AMOS with maximum likelihood estimation method to address the issues of convergent and discriminant validity (Anderson and Gerbing, 1988; 
Jöreskog \& Sörbom, 1993). The confirmatory factor analysis exposed the need to remove some items from the model (four items from store image, two statements from each following construct: familiarity; price consciousness and private label brand loyalty respectively, one item from quality consciousness, three statements from each following construct: national brand loyalty; attitudes toward private label brand products and store loyalty), due to their low standardized factor loading which was below the minimum recommended cut-off point of 0.50 . Table (1) reveals the confirmatory factor analysis results which shows that the items of every construct loaded successfully on a single factor and all standardized loadings are greater than 0.50 (Anderson and Gerbing, 1988) with values ranging from 0.610 to 0.893 and significant with a reliability level of $95 \%$ which discloses a strong convergent validity.

Table 1. Factor analysis

\begin{tabular}{|l|l|c|c|c|c|}
\hline Constructs & \multicolumn{1}{|c|}{ Measures } & $\begin{array}{c}\text { Factor } \\
\text { loading }\end{array}$ & C.R. & $\begin{array}{c}\text { R- } \\
\text { square }\end{array}$ & $\begin{array}{c}\text { P- } \\
\text { value }\end{array}$ \\
\hline Store Image (SI) & $\begin{array}{l}\text { (S) store provides } \\
\text { variety of products }\end{array}$ & 0.688 & -0.473 & $* * *$ \\
\hline SI1 & $\begin{array}{l}\text { The products of this } \\
\text { store are of good value } \\
\text { for money }\end{array}$ & 0.661 & 6.553 & 0.437 & $* * *$ \\
\hline SI7 & $\begin{array}{l}\text { Overall, I have positive } \\
\text { attitude toward this } \\
\text { store }\end{array}$ & 0.728 & 6.540 & 0.530 & $* * *$ \\
\hline Familiarity with private label & $\begin{array}{l}\text { I am quite familiar with } \\
\text { private label brand }\end{array}$ & 0.610 & & 0.372 & $* * *$ \\
\hline FAM2 & $\begin{array}{l}\text { I can associate private } \\
\text { label brand with their } \\
\text { characteristics (i.e good } \\
\text { price, quality, etc) }\end{array}$ & 0.741 & 9.876 & 0.372 & $* * *$ \\
\hline FAM3 & & & & \\
\hline
\end{tabular}




\begin{tabular}{|c|c|c|c|c|c|}
\hline FAM5 & $\begin{array}{l}\text { I know the available } \\
\text { private label brands well }\end{array}$ & 0.717 & 9.462 & 0.514 & $* * *$ \\
\hline \multicolumn{6}{|c|}{ Price Consciousness (PC) } \\
\hline PC2 & $\begin{array}{l}\text { When buying a brand, I } \\
\text { look for the cheapest } \\
\text { brand available }\end{array}$ & 0.735 & & 0.540 & $* * *$ \\
\hline PC3 & $\begin{array}{l}\text { When it comes to } \\
\text { buying, I rely heavily on } \\
\text { price }\end{array}$ & 0.815 & 7.429 & 0.664 & $* * *$ \\
\hline \multicolumn{6}{|c|}{ Quality Consciousness (QC) } \\
\hline QC1 & $\begin{array}{l}\text { In general, I usually try } \\
\text { to buy the best overall } \\
\text { quality }\end{array}$ & 0.772 & & 0.596 & $* * *$ \\
\hline QC2 & $\begin{array}{l}\text { Getting very good } \\
\text { quality is very important } \\
\text { to me }\end{array}$ & 0.866 & 10.835 & 0.750 & $* * *$ \\
\hline \multicolumn{6}{|c|}{ National brand loyalty (NBL) } \\
\hline NBL1 & $\begin{array}{l}\text { When I buy a national } \\
\text { brand, I always feel that } \\
\text { I am getting a good deal. }\end{array}$ & 0.803 & & 0.645 & $* * *$ \\
\hline NBL2 & $\begin{array}{l}\text { I prefer to buy national } \\
\text { brands even though there } \\
\text { are other private label } \\
\text { brands (store brands) } \\
\text { with similar } \\
\text { characteristics. }\end{array}$ & 0.860 & 16.546 & 0.740 & $* * *$ \\
\hline NBL6 & $\begin{array}{l}\text { I recommend my friends } \\
\text { and family to buy } \\
\text { national brands }\end{array}$ & 0.670 & 12.805 & 0.449 & $* * *$ \\
\hline \multicolumn{6}{|c|}{ Attitude toward private label brand (ATI) } \\
\hline ATI2 & $\begin{array}{l}\text { I love it when private } \\
\text { label brands are } \\
\text { available for the product } \\
\text { categories I purchase }\end{array}$ & 0.777 & & 0.604 & $* * *$ \\
\hline ATI3 & $\begin{array}{l}\text { For most product } \\
\text { categories, the best buy } \\
\text { is usually the private } \\
\text { label brand. }\end{array}$ & 0.725 & 10.507 & 0.526 & $* * *$ \\
\hline ATI5 & $\begin{array}{l}\text { Considering value for } \\
\text { the money, I prefer }\end{array}$ & 0.681 & 9.992 & 0.464 & $* * *$ \\
\hline
\end{tabular}




\begin{tabular}{|c|c|c|c|c|c|}
\hline & $\begin{array}{l}\text { private label brands to } \\
\text { national brands. }\end{array}$ & & & & \\
\hline \multicolumn{6}{|c|}{ Private label brand loyalty (PLBL) } \\
\hline PLBL2 & $\begin{array}{l}\text { When making shopping, } \\
\text { private label brand in the } \\
\text { store are my first option. }\end{array}$ & 0.822 & & 0.676 & $* * *$ \\
\hline PLBL4 & $\begin{array}{l}\text { When the private label } \\
\text { brand I want to buy are } \\
\text { out of stock, even though } \\
\text { there are other } \\
\text { alternatives, I would still } \\
\text { prefer buying it. }\end{array}$ & 0.974 & 19.034 & 0.949 & $* * *$ \\
\hline PLBL5 & $\begin{array}{l}\text { I recommend my friends } \\
\text { and family to buy private } \\
\text { label brand. }\end{array}$ & 0.857 & 19.147 & 0.734 & $* * *$ \\
\hline \multicolumn{6}{|c|}{ Store Loyalty (SL) } \\
\hline SL1 & $\begin{array}{l}\text { I consider myself to be } \\
\text { loyal to the store. }\end{array}$ & 0.769 & & 0.591 & $* * *$ \\
\hline SL2 & $\begin{array}{l}\text { When making shopping, } \\
\text { the store would be my } \\
\text { first choice. }\end{array}$ & 0.848 & 11.432 & 0.719 & $* * *$ \\
\hline SL3 & $\begin{array}{l}\text { I intent to continue } \\
\text { shopping in this store. }\end{array}$ & 0.893 & 10.918 & 0.797 & $* * *$ \\
\hline
\end{tabular}

In addition, table (2) demonstrates the final measurement items along with the reliability for each item, composite reliability (CR), the average variance extracted (AVE) and the square roots of AVE for each construct. In relation with reliability, the Cronbach's alpha was calculated for each construct and showing satisfactory values exceeding the prescribed minimum criteria $(0.70)$ or reached close values (Nunnally, 1978; Hair et al., 2010) which ranged from 0.70 to 0.90 , the overall alpha value is 0.868 . In terms of the internal reliability, all constructs exhibit acceptable composite reliability values, exceeding the threshold of 0.70 (Bagozzi, 1994). The average variances extracted values were greater than 0.5 for each 
construct (Fornell and Larcker, 1981), confirming internal consistency and convergent validity. As for discriminant validity of constructs, in all cases the square roots of the variance extracted (AVEs) from each construct is greater than the absolute value of the correlation between each pair of construct (Fornell and Larcker, 1981) confirming adequate discriminant validity. Also, the normality for all the constructs items was checked using Skewness and Kurtosis (Bagozzi \& Yi, 1988). The results of skewness and kurtosis show that all the values fall within the acceptable range 1.0 to +1.0 . providing support for the normality (see table 3 ). To sum up, the findings of the measurement model test, demonstrate strong statistical indications that the present model shows satisfactory level of items reliability and construct validity suggested that it can be proceed with the evaluation of the structural model.

Table 2. Correlation coefficients among the constructs and Discriminant and convergent validity of study variables

\begin{tabular}{|c|c|c|c|c|c|c|c|c|c|c|c|c|}
\hline & mean & SD & C.R. & AVE & SI & FAM & NBL & $\overline{Q C}$ & $\mathbf{P C}$ & ATI & PLBL & SL \\
\hline SI & 3.93 & 1.38 & $\begin{array}{l}0.789 \\
\end{array}$ & 0.659 & 0.700 & & & & & & & \\
\hline FAM & 3.48 & 1.34 & 0.732 & 0.530 & $.280^{* *}$ & 0.740 & & & & & & \\
\hline NBL & 3.31 & 1.23 & 0.823 & 0.611 & $.259 * *$ & $.287^{* *}$ & 0.835 & & & & & \\
\hline QC & 4.13 & 1.41 & 0.804 & 0.673 & $.315^{* *}$ & $.389^{* * *}$ & $.388^{* *}$ & 0.820 & & & & \\
\hline PC & 2.91 & 1.11 & 0.784 & 0.549 & $.115^{*}$ & .074 & $.216^{* *}$ & -.011 & $\begin{array}{l}0.798 \\
\end{array}$ & & & \\
\hline ATI & 9.66 & 1.51 & 0.772 & 0.531 & $.319^{* * *}$ & $.421^{* * *}$ & $.208^{* *}$ & $.397^{* *}$ & $.303^{* *}$ & 0.746 & & \\
\hline PLBL & 2.76 & 1.02 & 0.917 & 0.786 & $.254 * *$ & $.348^{* * *}$ & .087 & $.272 * *$ & $.201 * *$ & $.589^{* * *}$ & 0.900 & \\
\hline SL & 3.54 & 1.21 & 0.876 & 0.703 & $.246 * *$ & $.360 * *$ & $.154 * *$ & $.227^{* *}$ & .078 & $.328 * *$ & $.377 * *$ & 0.824 \\
\hline \multicolumn{13}{|c|}{$\begin{array}{l}\text { Cronbach alpha of all constructs is } .868, \text { Cronbach's alphas are in diagonal cells. } * * \text { Correlation is } \\
\text { significant at the } 0.01 \text { level ( } 2 \text {-tailed), } * \text { Correlation is significant at the } 0.05 \text { level ( } 2 \text {-tailed). }\end{array}$} \\
\hline
\end{tabular}


Table 3. Descriptive statistics and normality tests of the constructs in the model

\begin{tabular}{|c|c|c|c|c|}
\hline & Mean & Std. Deviation & Skewness & Kurtosis \\
\hline SI1 & 3.97 & .816 & -.440 & -.336 \\
SI2 & 4.07 & .807 & -.797 & .454 \\
SI7 & 3.75 & 1.006 & -.592 & -.319 \\
FAM2 & 3.58 & 1.101 & -.651 & -.238 \\
FAM3 & 3.50 & .948 & -.475 & .057 \\
FAM5 & 3.37 & 1.011 & -.487 & -.055 \\
NBL1 & 3.43 & 1.030 & -.142 & -.355 \\
NBL2 & 3.28 & 1.125 & .034 & -.725 \\
NBL6 & 3.23 & 1.031 & .022 & -.403 \\
QC1 & 4.12 & .927 & -1.586 & 1.125 \\
QC2 & 4.15 & .979 & -1.391 & 1.047 \\
PC2 & 2.72 & 1.068 & .619 & -.092 \\
PC3 & 3.09 & 1.029 & .204 & -.433 \\
AT12 & 3.59 & .993 & -.313 & -.304 \\
AT13 & 3.07 & 1.021 & .016 & -.387 \\
AT15 & 3.00 & 1.070 & .073 & -.432 \\
PLBL2 & 2.71 & 1.044 & .393 & -.404 \\
PLBL4 & 2.70 & .987 & .177 & -.312 \\
PLBL5 & 2.89 & 1.007 & .106 & -.206 \\
SL1 & 3.38 & .947 & -.210 & -.185 \\
SL2 & 3.56 & .976 & -.595 & .348 \\
SL3 & 3.68 & .837 & -.424 & .489 \\
& & & & \\
\hline
\end{tabular}




\subsection{Analysis of the structural model}

Having established that the measurement model presents a good fit, the hypothesized relationships among constructs was examined by estimating a structural equation model through the Analysis of Moment Structures (AMOS) version 22 using Maximum Likelihood Estimate. The overall model fit was assessed using a number of measures namely, the chi-square goodness-of-fit test statistic, Normed Chi-Square $(\chi 2 / \mathrm{d} f) \leq 3$ the goodness-of-fit index (GFI) $\geq 0.90$, Adjusted goodness-of-fit index $(\mathrm{AGFI}) \geq 0.80$, the comparative fit index $(\mathrm{CFI}) \geq 0.90$, the root means square error of approximation (RMSEA) $\leq 0.08$, and the Tucker-Lewis Index (TLI) $\geq 0.90$, which are considered the most important fit indices.

The results show that the chi-square $(\chi 2)$ value of 273.097 with 161 degrees of freedom, was statistically significant $(p=.000)$ at the level of significance of 0.05 (table 4), which cannot be considered as reliable indicator of the goodness of fit regarding to its sensitivity to samples exceeding 200 units (Bollen, 1989). Thus, the study had been used alternative fit indexes to assess the model fit $\{\chi 2 / \mathrm{d} f$ (1.696); GFI (.934); AGFI (.896); CFI (.965); TLI (.950); RMSEA (0. .047); IFI (.966)\}, confirming acceptable fit of the proposed structural model and all the values were all inside the boundaries, table (4) illustrates the results of these indices.

Both table (4) and figure (2) depict the path coefficients related to each hypothesized relationship in the proposed model, as well as the variance explained $\left(\mathrm{R}^{2}\right)$ of the structural model. The results supported the conceptual proposed model and revealed that the six hypothesized relationships between variables were found statistically significant and only one hypothesis was failed to accept. The structural model indicates that the store image ( $\beta$ $=0.186, \mathrm{t}=2.858, \mathrm{p}<0.004)$, familiarity with private label 
brand $(\beta=0.606, \mathrm{t}=6.480, \mathrm{p}<0.000)$, and price consciousness $(\beta=0.500, \mathrm{t}=5.786, \mathrm{p}<0.000)$ were significantly and positively influencing consumers' attitudes toward private label brand products. On the other side, it was interesting to note that contrary to our belief, quality consciousness had a significant positive impact on the consumers' attitudes toward PLB ( $\beta=$ $0.190, \mathrm{t}=2.835, \mathrm{p}<0.005)$. Therefore, hypotheses $\mathrm{H} 1, \mathrm{H} 2$, and H3 respectively were fully supported by the obtained data, whereas H4 was rejected. In table (4) It can be seen that National brand loyalty had a negative influence on the consumers' attitudes toward private label brand product, but significantly affected $(\beta=-0.453, t=-0.5 .760, p=0.000)$, so hypothesis H5 is supported by the structural model. In turn, the squared multiple correlation value $\left(\mathrm{R}^{2}\right)$ of 0.748 proves that $74.8 \%$ of variation in the consumers' attitudes toward the private label brand product is caused by five exogenous constructs namely store image, familiarity with private label brand, price consciousness, quality consciousness and national private label brand. Finally, the results exhibited that consumers' attitudes toward private label brand had a stronger and positive impact $(\beta=0.712, t=10.533, p<0.000)$ on Private label brand loyalty than store loyalty $(\beta=0.600, \mathrm{t}=7.095, \mathrm{p}<$ $0.00)$ confirming hypotheses $\mathrm{H} 6$ and $\mathrm{H} 7$ respectively. Consumers' attitude toward private label brand products explains $50.8 \%$ and $23.7 \%$ respectively of the variation of the variables consumers' loyalty toward private label brand and store loyalty. These findings indicate that others determinants of private label brand products should be considered to increase the percentage of variance explained. 
Table 4. Path coefficients and significances

\begin{tabular}{|c|c|c|c|c|c|c|}
\hline $\mathbf{H P}$ & Structural Paths & $\begin{array}{c}\text { Estima } \\
\text { te }\end{array}$ & $\begin{array}{c}\text { Path } \\
\text { Coefficie } \\
\text { nt }\end{array}$ & t-value & $\mathbf{P}$ & Sig \\
\hline HP1 & $\begin{array}{l}\text { Store Image --------- } \\
\text { attitude towards private label } \\
\text { brand }\end{array}$ & 0.246 & 0.186 & 2.858 & $\begin{array}{c}0.00 \\
4\end{array}$ & Accepted \\
\hline HP2 & $\begin{array}{l}\text { Familiarity with PL---------- } \\
\text { Attitude towards private } \\
\text { label brand }\end{array}$ & 0.681 & 0.606 & 6.480 & $* * *$ & Accepted \\
\hline HP3 & $\begin{array}{l}\text { Price consciousness--------- } \\
\text { Attitude towards private } \\
\text { label brand }\end{array}$ & 0.483 & 0.500 & 5.786 & $* * *$ & Accepted \\
\hline HP4 & $\begin{array}{l}\text { Quality consciousness---------- } \\
\text {--Attitude towards private } \\
\text { label brand }\end{array}$ & 0.203 & 0.190 & 2.835 & $\begin{array}{c}0.00 \\
5\end{array}$ & rejected \\
\hline HP5 & $\begin{array}{l}\text { National brand loyalty--------- } \\
\text { - Attitude towards private } \\
\text { label brand }\end{array}$ & -0.417 & -0.453 & -5.760 & $* * *$ & Accepted \\
\hline HP6 & $\begin{array}{l}\text { Attitude towards private } \\
\text { label brand-------Private } \\
\text { label brand loyalty }\end{array}$ & 0.835 & 0.712 & 10.533 & $* * *$ & Accepted \\
\hline HP7 & $\begin{array}{l}\text { Attitude towards private } \\
\text { label brand-------Store } \\
\text { loyalty }\end{array}$ & 0.667 & 0.600 & 7.095 & $* * *$ & Accepted \\
\hline
\end{tabular}

Chi-Square statistic $=273.097 ; \mathrm{df}=161$, normed chi-square statistic $(\mathrm{CMIN} / \mathrm{DF})=1.696$; $\mathrm{p}$ value $=0.000 ;$ goodness - of-fit index $($ GFI $)=93.4 \%$; Comparative Fit Index $($ CFI $)=96.5 \%$, Adjusted goodness-of-fit index (AGFI) $=89.6 \%$, Tucker-Lewis Index $($ TLI $)=95 \%$, and Incremental Fit Index (IFI) $=\mathbf{9 6 . 6 \%}$, the Root Mean Square Error of Approximation $($ RMSEA $)=0.047$.

$* \mathbf{p}<0.05, * * \mathbf{p}<0.01, * * * \mathbf{p}<0.001$

\section{Discussion and Conclusion}

The purpose of this study is to explore the different antecedents related to the retailers and consumers which affected the consumers' attitudes toward the private label brands, as well as the consequences of the consumers' attitudes with respect to the private label loyalty and store loyalty in the Egyptian hypermarkets and supermarkets. Relying on the previous literature we proposed that the store image, familiarity with PLB 
products and price consciousness are positively influenced attitudes toward private label brand, whereas quality consciousness and national brand loyalty are negatively influenced attitudes toward PLBs. The results of this study supported six hypothesized directions and confirmed attitudes toward private label brand products as an important determinant of private label brand evaluations.

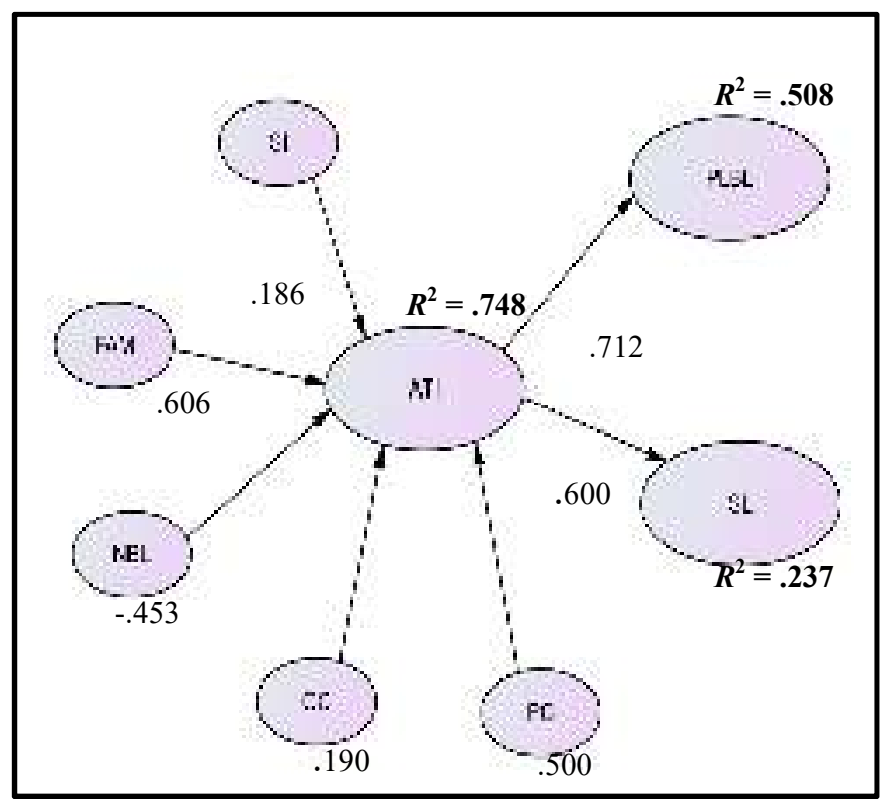

Figure 2. Structural Model results

The findings of this study show that the shoppers who have a positive store image perception are more likely to have positive attitudes toward the PLBs. Such this finding is consistent with Collins-Dodd., (2003), Semeijn et al., (2004) and Park et al., (2011) who reported that store image can be considered a vital predictor of attitude towards a private label brand product. Also, 
it is aligned with many studies that view store image play a significate role in the consumers' evaluation of private label brand product with respect to perceived quality to store brand, brand awareness, store brand equity and loyalty (Beristain and Zorrilla, 2011; Beneke and Zimmerman, 2014; Kremer and Viot, 2012; Beneke and Carter, 2015; Calvo-Porral et al., 2016) and also can contribute directly or indirectly to increase consumers' PLB purchase intention as cues for their decision making about PLBs (Diallo, 2012; Martenson, 2007; Richardson et al., 1994; Wu et al., 2011; Calvo-Porral and Levy-Mangin, 2015). This finding supports the notion that private label brand is considered to be an extension of the store image that taking in the consumers consideration to make inference about store brands purchase behavior.

In contrast to previous research that focused mainly on the influence of store brand familiarity on perceived quality and risk, in this research we investigated the influence of familiarity with private label brand on consumers' attitude toward PLBs. The results showed a strong significant and positive effect of familiarity on attitude toward PLBs. This result is in line with others previous researches' results which have confirmed that consumers' familiarity toward a specific's store brand affects their purchase perception and store brand choice such as Dick et al., (1995); Larocheet al., (1996); Richardson et al., (1996); Sethuraman and Code, 1999; Sheau-Fen et al., (2012); Diallo et al., 2013; Calvo-Porral and Levy-Mangin, 2015). Generally, consumers with higher familiarity with a specific PLB products are more favorably toward this brand and perceived them as high quality (Beneke and Carter, 2015), low risk products to choose (Diallo et al., 2013) and good value for money (Richardson et al., 1996; Sen and Johnson, 1997). On the other hand, consumers who have lack familiarity with such brands 
have a negative attitude toward them, are more likely to perceive them low quality, more risky choices and lower perceived value for money which lead the consumers to eliminate such these brands from their considerations (Dick et al., 1995). The study found that consumers' attitude toward PLB products is influenced by a positive and direct price consciousness. This result complies with many studies within the context of private label brand products (Baltas, 1997; Burton et al., 1998; Batra and Sinha, 2000; Jin and Suh, 2005; Yu Lin et al., 2009; SangCho et al., 2015). This result confirms the belief that priceconscious consumers have a favorable attitude toward private label brand, increase the perceived value for them (Bubio et al., 2015).

Contrary to the prevailing literature (Ailawadi et al., 2001, 2008; Richardson et al.,1996; De Vecchio, 2001; Miquel et al.,2002; Veloutsou et al., 2004), findings and the current study's hypothesis that quality conscious consumers have a negative attitude toward PLBs, we found surprising result that quality consciousness does not have a significant and negative influence on consumers' attitude towards PLBs. Such result can be interpreted that shoppers who are regularly buy PLB products are significantly more inclined to believe that private label brands offer same quality as national brands comparing to those who are reluctant to buy PLB (Dick et al., 1995). Consistent with previous studies Krishnamurthy and Raj (1991), Burton et al.,(1998), Garretson et al., (2002), Sang-Cho (2015), Broyles et al., (2011), the current study found that national brand loyalty negatively and significantly influenced consumers' attitudes toward PLBs. This means that shoppers who are loyal to manufacturer or national brand are unfavorable to be responsive to PLBs. 
With regard to the relationship between consumers' attitude towardsPLBs and both PLBs loyalty and store loyalty, we found that PLBs attitude strongly and positively affected PLB loyalty and store loyalty. These findings confirm those of prior studies (e.g., Sang Cho et al., 2015; Lombart and Louis, 2016; Ailawadi et al., 2001; Yang and Wang, 2010; Broyles et al., 2011). It could be explained that shoppers who are hold a highly positive private brand attitude are more willing to buy PLBs (CollinsDodd, 2003; Ailawadi et al., 2008; Yu Lin et al., 2009) and influence their choice (Diallo et al., 2013) that may lead them loving the brand and being a loyal for this brand and the store. Consequently, this result confirms that attitude toward PLBs is an important determinant of PLBs evaluations (Collins-Dodd, 2003).

\section{Management and Consumer Implications}

This study offers important and practical insights for retailers who intend to develop their private labels. According to the research findings, a retailer can develop an array of strategies. Firstly, the results indicated that shoppers use store image including service layout, merchandise, employees service, after sales services and location to make inferences about the quality of the PLB products (Richardson et al., 1994) which lead to favorable or unfavorable PLBs image or attitude before moving to others brand evaluations. Therefore, the retailer mangers should improve the store image by increasing product assortment, improving product quality, offering the products in the price worthy of value and pleasantly decorating the store (Wu et al., 2011), such these improvements consumers have taken on their considerations when evaluate the PLBs. Thus, managers have to focus on promote their PLB products using 
different associations such as low price, value for money which it seems efficient to improve the price positioning of the retailers special when consumers are more sensitive to the price (Kremer and Viot, 2012). Generally speaking, retail mangers must be aware of the different types of consumers by offering PLBs attract consumers not only in terms of price and quality but also image (Diallo et al., 2013). Besides, the current study focused on the importance of familiarity toward PLB as a critical determinant for attitude towards PLB and the findings confirmed the prior studies belief showing a significantly and positively influenced between them. Thus, retailer managers must be aware about the role of familiarity in building consumers awareness about their PLBs and enchase their prestige due to its affected on consumers' perceived quality, perceived risk and their choices. They could use different strategies to increase the familiarity with their PLBs by using in store taste tests, blind comparisons with national brands, distribute free samples, trial packs, issuing store brand coupons to shoppers of competing national brands at the checkout counter (Richardson et al., 1996), and increase the advertising and promotional campaigns of their PLBs.

Surprised result had been disclosed that the quality consciousness was positivity and significantly influenced attitudes toward PLBs which was different comparing to our belief. On the other side, price consciousness had a positive and significate impact on attitude towards PLBs. Based on these findings, retailer managers should segment the consumers based on price and quality consciousness to develop a suitable strategy dealing with each segment. Besides, managers should develop and implement strategies to reinforce the perceived quality of PLBs in order to overcome the stereotype that the PLB products are inferior in quality due to its lower price (Sheau-Fen et al., 
2012). It would be useful for the retailers to implement different strategies in order to achieve superior perceived quality comparing to the national brand such as investing more in the development of quality products or engaging in a strong partnership with suppliers to improve the ingredients quality of their products and the manufacturing process. Moreover, retailers should use extrinsic cues to enhance the quality consciousness of PLB products by using appealing packaging design, attractive labelling, display private label brand products near the leading national brands, cost effective advertising. Such these strategies help to create strong extrinsic cues which shoppers use to judge the PLBs quality and reduce the risk of having these products. Consequently, such these activities influence consumers' responses towards PLBs mainly the favorable one leading the consumers to become more loyal for the PLBs.

Finally, retailer managers must use their PLBs to build and their store loyalty by creating exclusive products which are consistent with their overall store image and their consumers expectations as having highly positive attitude toward such these brands.

\section{Limitations and further research}

This research has some limitations that would be suggest for future research. First, in reference to the measurement of constructs in the model, it would have been desirable to use a more complete measurement of store image which measuring by three dimensions only in this study. Second, it would be interested for others researchers to extend the study to other retail formats (such as the discount stores, convenience store and specialty store), types of distributor brands, product categories and product involvement, to explore the differences and changes that might occur depending on such these variables taking into 
considerations. Third, this research investigates the hypermarkets and supermarkets in the greatest Cairo only in Egypt, it would be useful to replicate this research in others cities or others Arabian countries, as most of the existing studies on PLBs were performed in Western countries (Diallo et al., 2013). Fourth, giving the growing interest in the field of private label brands it would be interesting to investigate and compare between the Egyptian store brand shoppers and non-store brand shoppers in terms of their attitudes towards these brands and the factors which affected them, which will bring further understandings. Fifth, it would be useful for future research to study the moderating influence of socio-demographic factors on the relationship between the attitude towards PLBs and others antecedents or PLBs purchase. Shukla et al., (2013), highlighted the importance role that socio-demographic factors such as age, income and education play as moderates' factors between psychographics factors and attitudes toward PLBs. Furthermore, a study comparing the attitudinal differences among the private label brands and national brand shoppers by re-examining the constructs employed in this study and may be added others variables such as socio-demographic will generate further insights in the Egyptian retailer context. 


\section{References}

1. Aaker, D., Joachimsthaler, E. (2009). Brand Leadership: Building Assets in an information Economy. Free Press, New York.

2. Agarwal, S., Teas, R. (2001). Perceived value: mediating role of perceived risk. Journal of Marking Theory and Practice, 9 (4): $1-14$.

3. Ailawadi, K., Gedenk, K., Neslin, S. (2001). Pursuing the value conscious consumer: private labels versus national brand promotions". Journal of Marking, 65 (1): 71-89.

4. Ailawadi, K., Keller, K. (2004). Understanding retail branding: conceptual insights and research priorities. Journal of Retailing, 80(4): 331-342.

5. Ailawadi, K.L. (2001). The retail power-performance conundrum: what have we earned?, Journal of Retailing, 77: 299-318.

6. Ailawadi, Kusum L., Koen Pauwels \& Jan-Benedict E. M. Steenkamp. (2008). Private label and Store Loyalty Source, Journal of Marketing, 72(6): 19-30.

7. Alba, J.W. and Hutchinson, J.W. (1987). Dimensions of consumer expertise.Journal of Consumer Research,13 (1): 41154

8. Angell, R. J., Megicks, P., Memery, J. \& Heffernan, T. W. (2014). Older shopper types from store image factors. Journal of Retailing and Consumer Services, 21: 92-202.

9. Anderson, J. and Gerbing, D. (1988). Structural equation modelling in practice: A review and recommended two-step approach. Psychological Bulletin, 103(3): 411-423.

10. Angell, Robert J., Megicks, Phil, Memery, Juliet, and Heffernan, Troy W. (2014). Older shopper types from store image factors. Journal of Retailing and Consumer Services 21: 92-202. 
11. Arens, W., Weigold, M., Arens, C. (2012). Contemporary Advertising and Integrated Marketing Communications, 14th edition. McGraw-Hill, New York.

12. Bagozzi, R.P. (1994). The effects of arousal on the organization of positive and negative affect and cognitions: application to attitude theory. Structural Equation Modeling, 1: 222-252.

13. Bagozzi, R. P. \&Yi, Y. (1988). On the evaluation of structural equation models. Journal of the Academy of Marketing Science, 16 (1): 74-94.

14. Baker, J., Grewal, D., Parasuraman, A. (1994). The influence of store environment on quality and store image. Journal of the Academy of Marketing Science, 22 (4): 328-339.

15. Ballester, E. D., Navarro, A. and Sicilia, M. (2012). Revitalising brands through communication messages: the role of brand familiarity. European Journal of Marketing, 46 (1/2): 31-51.

16. Baltas, G. (2000). A combined segmentation and demand model for store brands. European Journal of Marketing, 37 (10): 1499-513.

17. Baltas, G. (1997). Determinants of store brand choice: a behavioral analysis. Journal of Product \& Brand Management, 6 (5): 315-324.

18. Baltas, G. \& Argouslidis, C. (2007). Consumer characteristics and demand for store brand. International Journal of Retail and Distribution Management, 3 (5): 328-341. 19. Bao, Y., Bao, Y. \& Sheng, S. (2011). Motivating purchase of private brands: Effects of store image, product signatureness and quality variation. Journal of Business Research, 64: 220226. 
20. Bapat, D. (2017). Impact of brand familiarity on brands experience dimensions for financial services brands. International Journal of Bank Marketing, 35(4): 637-648.

21. Batra, R. \& Sinha, I. (2000). Consumer-level factors moderating the success of private label brands. Journal of Retailing, 76: 175-91.

22. Beneke, J. \& Carter, S. (2015). The development of a consumer value proposition of private label brands and the application in a South African retail context. Journal of Retailing and Consumer Services, 25: 22-35.

23. Beneke, J. \& Zimmerman, N. (2014). Beyond private label panache: the effect of store image and perceived price on brand prestige. Journal of Consumer Marketing, 31(4): 301-311.

24. Beristain, J.J. \& Zorrilla, P. (2011). The relationship between store image and store brand equity: A conceptual framework and evidence from hypermarkets.Journal of Retailing and consumer services, 18:562-574.

25. Blattberg, R. C., \& Neslin, S. A. (1990). Sales promotion: Concepts, methods, and strategies. (1st ed.). Englewood Cliffs, NJ: Prentice Hall.

26. Bollen, K.A. (1989). Structural equations with latent variables. New York: Wiley.

27. Brown, J., Broderick, A. \&Lee, N. (2007). Word of mouth communication within online communities: conceptualizing the online social network. Journal of interactive marketing, 21 (3): $2-20$.

28. Broyles, A.S., Ross, R.H., Davis, D. \& Leingpibul, T. (2011). Customers' comparative loyalty to retail and manufacturer brands. Journal of Product \&Brand Management, 20 (3): 205-215. 
29. Burt, S.L. \& Sparks, L. (2002). Branding experiences: corporate branding in retail. Corporate Reputation Review, 5 $(2 / 3): 193-213$.

30. Burton, S., Lichtenstein, D.R., Netemeyer, R.G. \& Garretson, J.A. (1998). A scale of measuring attitude toward private label products and an examination of its psychological and behavioral correlates. Journal of the Academy of Marketing Science, 26: 293-306.

31. Calvo-Porral, C. \& Levy-Mangin, J.P. (2016). Food private label brands: the role of consumer trust on loyalty and purchase intention. British Food Journal, 118(3):679-696.

32. Chang, C., Tu, C. (2005). Exploring store image, customer satisfaction and customer loyalty relationship: Evidence from Taiwanese hypermarket industry. Journal of American Academy of Business, 7 (2):197-202.

33. Cho, Y.S., Rha, H- Su., \&Burt, S. (2015). The impact of customer awareness of manufacturer name disclosure on retail brand attitudes and loyalty in Korea. Journal of Retailing and Consumer Services, 22: 128-137.

34. Collins-Dodd, C. \&Lindley, T., (2003). Store brand and retail differentiation: the influence of store image and store brand attitude on store own brand perceptions. Journal of Retailing and Consumer Services, 10 (6): 345-352.

35. Corstjens, M.\& Lal, R. (2000). Building store loyalty through store brands. Journal of Marketing Research,37 (3): 281-91.

36. DelVecchio, D.S., (2001). Consumer perceptions of private label quality: The role of product category characteristics and consumer use of heuristics. Journal of Retailing and Consumer Services, 8: 239-249.

37. De Wulf, K., Gaby Odekerken-Schröder, Goedertier, F. \& Van Ossel, G. (2005). Consumer perceptions of store brands 
versus national brands. Journal of Consumer Marketing, 22 (4): 223-232.

38. Dhar, S.K. \& Hoch, S.J. (1997). Why store brand penetration varies by retailer. Marketing Science, 16: 208-23.

39. Diallo, M. F. (2012). Effects of store image and store brand price-image on store brand purchase intention: Application to an emerging market. Journal of Retailing and Consumer Services, 19: 360-367.

40. Diallo, M.F., Chandon, J-L, Cliquet, G. \&Philippe, J. (2013). Factors influencing consumer behaviour towards store brands: evidence from the French Market. International Journal of Retail \& Distribution Management, 41(6): 422-441.

41. Dick, A., Jain, A.\&Richardson, P. (1995). Correlates of store brand proneness: some empirical observations. Journal of Product \& Brand Management, 4(4): 15-22.

42. Dodds, W. B. (1995). Market Cues Affect on Consumers' Product Evaluations, Journal of Marketing Theory and Practice,3 (2) Spring: 50-63.

43. Dursun, I., Kabadayi, E., Alan, A. \& Sezen, B. (2011). Store brand purchase intention: effects of risk, quality, familiarity and store brand shelf space, $7^{\text {th }}$ International Strategic Management Conference, Procedia-Social and Behavioral Sciences, 24: 1190-1200

44. Engel, J.F., Blackwell, R.D. \& Miniard, P.W. (1995). Consumer Behavior, (8th Edition.) The Dryden Press, Fort Worth.

45. Erdem, T. \& Swait, J. (1998). Brand equity as a signaling phenomenon. Journal of Consumer Psychology, 7 (2):131-157.

46. Fan, J. X. \& Xiao, J. J. (1998). Consumer DecisionMaking Styles of Young-Adult Chinese, The Journal of Consumer Affairs, 32 (2): 275-294. 
47. Farhangmehr, M., Marque, S. and Silva, J. (2001). Hypermarkets versus traditional retail stores consumers' and retailers' perspectives in Braga: a case study. Journal of Retailing and Consumer Services, 8 (4): 189-198.

48. Fornell, C. \&Larcker, D. (1981). Evaluating Structural Equation Models with Unobservable Variables and Measurement Error. Journal of Marketing Research, 18(1): 3950 .

49. Garretsona, J. A., Fisherb, D.\& Burton, S. (2002). Antecedents of private label attitude and national brand promotion attitude: similarities and differences. Journal of Retailing,78: 91-99.

50. Glynn, M. S. and Chen, S. (2009). Consumer-factors moderating private label brand success: further empirical results. International Journal of Retail \& Distribution Management, 37(11): 896-914.

51. Goldsmith, R. E., Flynn, L. R., Goldsmith, E. \& Stacey, E. Craig. (2010). Consumer attitudes and loyalty towards private brands. International Journal of Consumer Studies, 34: 339348.

52. Grewal, D., Krishnan, R., Baker, J. \& Borin, N. (1998). The effect of store name, brand name and price discounts on consumers' evaluations and purchase intentions. Journal of Retailing, 74 (3): 331-352.

53. Hair, J., Black, W., Babin, B. and Anderson, R. (2010). Multivariate data analysis: A global perspective (7th ed.). Pearson Education International.

54. Hartman, K.B. \& Spiro, R.L. (2005). Recapturing store image in customer-based store equity: a construct conceptualization. Journal of Business Research, 58 (8): 11121120. 
55. Hoch, S.J. \& Banerji, S. (1993). When do private labels succeed?. Sloan Management Review, 17 (5):368-89.

56. Hopkins, C. \& Alford, B.L. (2001). A new sevendimensional approach to measuring the retail image construct. Academy of Marketing Science Journal, 5 (2): 105-113.

57. Jaafar, S., Lalp, P.\&Naba, M. (2012). Consumers' perceptions, attitudes and purchase intention towards private label food products in Malaysia. Asian Journal of Business Management Science, 2(8): 73-90.

58. Jacoby, J. \& Mazursky, D. (1984). Linking brand and retailer images: do the potential risks outweigh the potential benefits?. Journal of Retailing, 60 (2):105-22.

59. James, D.L., Durand, R.M. \& Dreves, R.A. (1976). The use of a multi-attribute model in a store image study. Journal of Retailing, 52 (2): 23-32.

60. Jin, B. \& Suh, Y.G. (2005). Integrating effect of consumer perception factors in predicting private brand purchase in a Korean discount store context. Journal of Consumer Marketing, 22 (2): 62-71.

61. Jöreskog \& Sörbom.(1993). LISREL8: Structural Equation Modelling with the SIMPLIS Command Language, Chicago: Scientific Software.

62. Kara, A., Rojas-Mendez, J.I., Kucukemiroglu, O.\& Harvard, T. (2009). Consumer preferences of store brands: role of prior experiences and value consciousness. Journal of Targeting Measurement and Analysis for Marketing, 17(2):127137.

63. Kent, R.J. and Allen, C.T. (1994). Competitive interference effects in consumer memory for advertising: the role of brand familiarity. Journal of Marketing, 58(3): 97-105. 64. Knox, Simon D., \& Dension, Tim J. (2000). Store loyalty: its impact on retail revenue.An empirical study of purchasing 
behaviour in the UK. Journal of Retailing and Consumer Services, 7:33- 45.

65. Kremer, F. \& Viot, C. (2012). How store brands build retailer brand image. International Journal of Retail \& Distribution Management, 40 (7): 528 - 543.

66. Krishnmaurthi, L., \& Raj, S. P. (1991). An empirical analysis of the relationship between brand loyalty and consumer price elasticity. Marketing Science, 10(2): 172-183.

67. Kumar, N., Steenkamp, J. (2007). Private Label Strategy: How to Meet the Store Brand Challenge, Harvard Business School Press, Cambridge.

68. Kwon, Kyoung-Nan, Lee, Mi-Hee \& Kwon, Yoo Jin. (2008). The effect of perceived product characteristics on private brand purchases. Journal of Consumer Marketing, 25 (2): $105-114$.

69. Lamey, L., Deleersnyder, B., Dekimpe, M.G., Steenkamp, J.-B.E.M. (2007). How business cycles contribute to privatelabel success: evidence from the United States and Europe.Journal of Marketing, 71 (1): 1-15.

70. Laroche, M., Kim, C.\& Zhou, L. (1996). Brand Familiarity and Confidence as Determinants of Purchase Intention: An Empirical Test in a Multiple Brand Context. Journal of Business Research, 37: 115-120.

71. Lichtenstein, D.R., Bloch, P.H. \&Black, W.C. (1988). Correlates of price acceptability. Journal of Consumer Research, 15: 243-252.

72. Lindquist, J.D. (1974). Meaning of image - a survey of empirical and hypothetical evidence. Journal of Retailing, 50 (4): $29-38$.

73. Lombart, C.\& Louis, D. (2016). Sources of retailer personality: Private brand perceptions. Journal of Retailing and Consumers Services, 28: 117-125. 
74. Martenson, R. (2007). Corporate brand image, satisfaction and store loyalty: a study of the store as a brand, store brands and manufacturer brands. International Journal of Retail \& Distribution Management, 35 (7): 544-55.

75. Martineau, P. (1958). The personality of the retail store. Harvard Business Review, 36: 47-55.

76. Mazursky, D. \&Jacoby, J. (1986). Exploring the development of store images. Journal of Retailing, 62(2): 145165.

77. Miquel, S., Caplliure, E.M. and Aldas-Manzano, J. (2002). The effect of personal involvement on the decision to buy store brands. Journal of product and Brand Management, 11(1):6-18.

78. Nunnally, J.C. (1978). Psychometric Theory, McGrawHill Book Company, New York, NY.

79. Oliver, R.L. (1980). A cognitive model of the antecedents and consequences of satisfaction decisions. Journal of Marketing Research, 17 (4): 460-469.

80. Oliver, R.L. (1997). Satisfaction: A Behavioral Perspective on the Consumer, McGraw-Hill, New York, NY.

81. Park, J. \& Stoel, L. (2005). Effect of brand familiarity, experience and information on online apparel purchase. International Journal of Retail \& Distribution Management, 33 (2):148-160.

82. Park, J.Y., Park, K. and Dubinsky, A.J. (2011). Impact of retailer image on private brand attitude: Halo effect and Summary construct. Australian Journal of Psychology, 63: 173184.

83. Pepe, M. S., Abratt, R., \& Dion, P. (2011). The impact of private label brands on customer loyalty and product category profitability, Journal of Product \& Brand Management, 20(1): 27-36, 
84. PLMA, (2009) Store brands and the recession. PLMA Consumer Research Report, Private Label Manufacturers Association, retrieved on December 15, 2010 from: http://www.plma.com/PLMA_Store_Brands_and the Recessio n.pdf.

85. Quelch, J. \& Harding, D. (1996). Brands versus private labels: fighting to win. Harvard Business Review, 74 (1): 99.

86. Reardon, J., Miller, C.E.\& Coe, B. (1995). Applied scale development: measurement of store image. Journal of Applied Business Research, 11, (4): 85-93.

87. Richardson, P.S. (1997). Are store brands perceived to be just another brand?. Journal of Product \& Brand Management, 6 (6): 388-404.

88. Richardson, P. S., Jain, A.K. \& Dick, A. (1996). Household store brand proneness: a framework. Journal of Retailing, 72: 159-85.

89. Rita, M. (2007). Corporate brand image, satisfaction and store loyalty, International Journal of Retail \& Distribution Management, 35 (7): 544 - 555.

90. Rondan Cataluna, F.J., Garcia, A.N. \&Phau, I. (2006). The influence of price and brand loyalty on store brands versus national brands. the international Review of Retail, Distribution and Consumer Research, 16 (4): 433-452.

91. Rubio, N., Oubiña, J. \&Suárez, Mónica Gómez. (2015). Understanding brand loyalty of the store brand's customer base. Journal of Product \& Brand Management, 24 (7): 679 - 692.

92. S., Gates, R. (1993). An attribute-anchored conjoint approach to measuring store image. International Journal of Retail and Distribution Management, 21 (5): 30$\} 39$.

93. Scott-Morton, F. \& Zettelmeyer, F. (2004). The strategic positioning of store brands in retailer-manufacturer negotiations. Review of Industrial Organization, 24 (2): 161-94. 
94. Semeijna, J., Van Riel, A.C.R. \& Ambrosini, A. B. (2004). Consumer evaluations of store brands: effects of store image and product attributes. Journal of Retailing and Consumer Services, 11: 247-258

95. Sen, S., Johnson, E.J., Stanforth, N.F., Lennon, S.J. \& Moore, S. (2000). Perceived risk and purchase intent associated with television shopping, Frontiers in Direct and Interactive.Marketing Research Proceeding,3: 53-64.

96. Sethuraman, R., Cole, C. (1999). Factors influencing the price premiums that consumers pay for national brands over store brands. Journal of Product and Brand Management, 8 (4): $340-351$.

97. Sheau-Fen, Y. Sun-May, Leong \& Yu-Ghee, W. (2012). Store brand proneness: effects of perceived risks, quality and familiarity. Australasian Marketing Journal, 20: 48-58

98. Shukla, P., Banerjee, M. \& Adidam, P.TEJ. (2013). The moderating influence of socio-demographic factors on the relationship between consumer psychographics and the attitudes towards private label brands. Journal of Consumer Behavior, 12: 423-435.

99. Sinha, I. \& Batra, R. (1999). The effect of consumer price consciousness on private label purchase. International Journal of Research in Marketing, 16: 237-251

100. Soyoung, K. \& Byoungho, J. (2001). An evaluation of the retail service quality scale for U.S. and Korean customers of discount stores. Advances in Consumer Research, 28:169-176

101. Sproles, G.B. \& Kendall, E.L. (1986). A methodology for profiling consumers' decision-making styles. The Journal of Consumer Affairs, 20 (2): 267-279.

102. Steenkamp, J.B.E.M., Koll, O. \& Geyskens, I. (2004). Understanding the drivers of private labels success: a western 
European perspective 2004. AiMark, Tilburg University, Europanel GfK panel Services Benelux, Dongen.

103. Steenkamp, Jan-Benedict E.M.\&Marnik G. D. (1997). The Increasing Power of Store Brands: Building Loyalty and Market Share. Long Range Planning, 30 (6): 917-30.

104. Vahie, A. \&Paswan, A. (2006). Private label brand image: its relationship with store image and national brand. International Journal of Retail \& Distribution Management, 34 (1): $67-84$.

105. Veloutsou, C., Gioulistanis, E. \& Moutinho, L. (2004). Own labels choice criteria and perceived characteristics in Greece and Scotland: factors influencing the willingness to buy. Journal of Product and Brand Management,13(4): 228-241.

106. Wu, P.C.S., Yuh Yeh, G.Y. \& Hsiao, C.R. (2011). The effect of store image and service quality on brand image and purchase intention for private label brands. Australasian Marketing Journal, 19: 30-39.

107. Yang, D. \& Wang, X. (2010). The effects of 2 -tier Store Brands' perceived Quality, Perceived Value, Brand Knowledge, and Attitude on store Loyalty. Journal of Marketing Science, 4 (1): 69-85.

108. Yasin, B. (2009). The Role of Gender on Turkish Consumers' Decision-Making Styles. Istanbul University Conference.

https://www.researchgate.net/publication/261702076

109. Yoo, B. \& Donthu, N. (2001). Developing and validating a multidimensional consumer-based brand equity scale. Journal of Business Research, 52 (1): 1-14.

110. Yu Lin, C., Marshall. D. \& Dawson. J. (2009). Consumer attitudes towards a European Retailer's private brand food products: an integrated model of Taiwanese consumers. Journal of Marketing Management, 25(9):875-891. 
111. Yoo, B., Donthu, N. \& Lee, S. (2000). An examination of selected marketing mix elements and brand equity. Journal of the Academy of Marketing Science,28 (2): 195-211.

112. Zajonc, R. B., \& Markus, H. (1982). Affective and Cognitive Factors in Preferences. Journal of Consumer Research 9 (September 1982): 123-131.

113. Zeithaml, V.A., Leonard, L.B. \& Parasuraman. A. (1996). The behavioural consequences of service quality. Journal of Marketing, 60 (2):31-46.

114. Zielke, S.\&Dobbelstein, T. (2007). Customers' willingness to purchase new store brands. Journalof Product \& Brand Management, 16(2): 112-121 